\section{Autoantikörper gegen Enterozyten}

W. Stöcker

Euroimmun Medizinische Labordiagnostika AG, Lübeck, Deutschland

Synonym(e) Kolonepithel-Antikörper

Englischer Begriff antibodies to colon epithelium

Definition Autoantikörper gegen Antigene des Darmepithels. Im Gegensatz zu den diagnostisch viel wichtigeren - Autoantikörper gegen intestinale Becherzellen haben diese Antikörper diagnostisch keine Relevanz.

Funktion - Pathophysiologie Das Immunsystem des Darms scheint besonders bei Morbus Crohn infolge krankheitsspezifischer Autoimmunreaktionen Antikörper gegen alle möglichen in der Darmwand präsenten Antigene zu produzieren, bedingt durch die Adjuvanswirkung der spezifischen Auseinandersetzung des Immunsystems mit dem relevanten Autoantigen. Ebenso wie Antikörper gegen das Kolonepithel finden sich bei Morbus Crohn auch - Antikörper gegen Saccharomyces cerevisiae (ASCA) und Antikörper gegen verschiedene Infektionserreger im Serum der Patienten.

Untersuchungsmaterial Serum oder Plasma.
Probenstabilität Autoantikörper sind bei $+4{ }^{\circ} \mathrm{C}$ bis zu 2 Wochen lang beständig, bei $-20^{\circ} \mathrm{C}$ über Monate und Jahre hinweg.

Analytik Für die Untersuchung der Autoantikörper gegen Enterozyten wird die indirekte Immunfluoreszenz ( $\triangleright$ Immunfluoreszenz, indirekte) eingesetzt, Ausgangsverdünnung ist 1:10. Es reagiert das Zytoplasma der Epithelzellen des Darms, einschließlich der Becherzellen. Zu den verschiedenen Darmabschnitten besteht die gleiche Affinität.

Interpretation Unter identischen Inkubationsbedingungen findet man bei Morbus Crohn 39 \% positive Ergebnisse $(\triangleright$ Autoantikörper gegen Pankreassekret treten mit der gleichen Prävalenz auf, zeigen aber keine Kreuzreaktion; - Kreuzreaktivität), bei Colitis ulcerosa $33 \%$, bei Zöliakie $10 \%$ und bei Gesunden $14 \%$.

Diagnostische Wertigkeit Wegen der geringen Krankheitsspezifität lohnt es sich nicht, diese Autoantikörper weiter in Betracht zu ziehen.

\section{Literatur}

Stöcker W, Otte M, Ulrich S et al (1987) Autoimmunity to pancreatic juice in Crohn's disease. Results of an autoantibody screening in patients with chronic inflammatory bowel disease. Scand J Gastroenterol Suppl 139:41-52 